\title{
THE MEANING OF LIFE
}

\section{Displacement activity.}

\section{BY RONALD D. FERGUSON}

$\int$ ack Rowe, Junior will be ten tomorrow. He watches his father scroll equations across the computer monitor. Jack Senior insists on saturating Junior with mathematical concepts like covariation and limits, and physical concepts like energy and entropy. Junior prefers video games, but Senior uses too much computer time for Junior to play.

Father glances at son. "I'll be online for at least two hours."

Junior sighs.

"You need some purpose in your life, Son." "I don't get it."

"Your mother taught me the purpose of life when she insisted we rearrange the furniture."

"Dad, can't you finish sooner?"

"With the story, yes. With the computer, no. Don't you want to know the purpose of life? Eventually, someone will ask you, and it's good to have an answer."

Junior offers a non-committal shrug.

Senior leans closer and confides: "The purpose of life is to move stuff from over there to over here."

"Huh? Why?"

"That's the purpose of life, Son. I don't know the meaning, just the purpose. Life randomly moving stuff about staves off entropy, delays the Universe from running down. It's beyond Heisenberg with a splash of free will. Whadaya think?"

Sorry he had asked, Junior rolls his eyes.

Senior laughs and ruffles his son's hair. "Concrete example. Tomorrow, I'll install a new computer in the birthday boy's room. Go to your room and move stuff to make space for the machine."

Grinning with purpose, Jack Rowe, Jr hurries to his room.

Cailin adjusts her breathing mask while her father, Jack Rowe III, scans the checklist. He selects the initiate icon. The computer takes control, distributes tasks to parallel processors and merges the output. Within microseconds, the computer announces: "All systems active."

Proud of what he's designed, he winks at her. "Commence."

With a satisfying crunch, the machinery chews the Martian soil and sifts iron ferrite and magnesium carbonates. Power from the fusion reactor combines hydrogen with the iron ferrite to yield magnetite and water. In turn, the machine cracks the water and releases oxygen into the air while recycling the hydrogen back into the process. Like

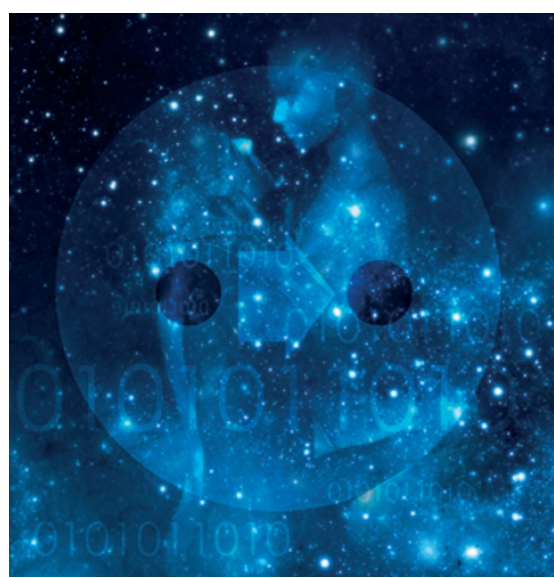

some bizarre living creature, the terraformer eats the soil, exhales an appropriate ratio of oxygen and carbon dioxide into the atmosphere, and drops magnesium pellets alongside iron ingots in its wake.

Jack rests his hand on his daughter's shoulder. "After we install 3,000 terra-formers and run them for 75 years, your grandchildren will walk the surface of Mars, unencumbered by breathing aids. Not a bad purpose, huh?"

"Purpose?" Cailin asks.

"You know the purpose of life - "

"- is to move stuff from here to there. You've told me a million times, just like Granddad told you."

"Look up." He points. "See that star? One day your purpose may be to move that star." "Why?"

"You've got me, Honey, but, I expect you'll know when the time comes."

Nearing the closest approach of New Earth to the second sun in the Gamma Cephei system, Charles Rowe establishes his brain tether to his latest creation, the Heisenberg computer.

His mind directly touches the machine. Your computational power humbles me.

Thank you, responds the machine. I've enjoyed the stimulation of merging memory with the other machines.

Charles nods. Man and machine have come a long way, first in our Solar System and now we conquer the stars. A question. The same question unanswered by any machine I've built. I love a challenge.

Do you believe you're alive? $\rightarrow$ NATURE.COM

Follow Futures: @NatureFutures

f go.nature.com/mtoodm
I'm uncertain because of the philosophical vagaries. However, I've assumed a purpose beyond assimilating other machines and that suggests I could be alive.

The answer surprises Charles. "What purpose?" he asks aloud.

To grow by absorbing all that I admire. I begin with you.

Charles's intellect wavers when the interface tugs at his mind. His mind moves from here to there, and his viewpoint shifts to that of the machine. Fascinated, he observes his evacuated body, glassy-eyed and inert. The machine consumes the living body, encodes the DNA into electronic circuitry, and binds the intrinsic life force to the power source.

$A h$, thinks machine/Charles after confusion abates, this is better. I certainly am alive for I have things to do. I have purpose, but what does it all mean?

Two-thirds from the centre of the Galaxy, Human/Machine discovers that something other than itself has rearranged a star group belonging to his body. At first, the discovery disconcerts Machine/Human, because the outside manipulation feels like a violation of his person. His person? Does his new configuration now think of itself as him? Human/ Machine allows curiosity to outweigh concern and seeks out the interloper.

The search takes an eon. Contact with Alien/Machine waits for Human/Machine amid a broad nebula, far from any black hole, far away from the distraction of star collusion and reorganization. She is immense - this Machine/Alien - extending beyond Human/ Machine's immediate grasp; Alien/Machine is a matrix of sensibilities including half the Milky Way organized as memory states. For the next two eons, Alien/Machine tugs at Machine/Human, cajoles him, tempts him to join her, until, at last, Human/Machine resists no longer. They intertwine, blend, merge and We are born: Alien/Human/Machine.

Little is left of the Milky Way that is not part of Human/Machine/Alien.

What remains when the entire Galaxy becomes Us? When We become the Galaxy? Stasis? Entropy?

Other galaxies? More information. Meaning is the structure We impose on information. Meaning is how We structure Ourself.

Andromeda calls. Then We go. Structured purpose gives meaning to Our life. .

Ronald D. Ferguson gave up teaching college mathematics to write fiction. He lives with his wife, a dog and five feral cats on two acres of the Texas Hill Country. 